JNE 5 (1) (2019)
UNNES
Journal of Nonformal Education
http://journal.unnes.ac.id/nju/index.php/jne

\title{
Women Empowerment in Disaster Vulnerable Village Through Vocational Life Skill Education Based on Utilization of Local Potential
}

\author{
Entoh Tohani ${ }^{\bowtie}$, Iis Prasetyo, RB. Suharta \\ Department of Nonformal Education, Faculty of Education, Universitas Negeri Yogyakarta, \\ Indonesia
}

DOI: https://doi.org/10.17087/jne.v5i1

\section{Articles Info}

\section{History Articles:}

Received 10 December 2018

Approved 28 January 2019

Published 1 February 2019

\section{Keywords:}

empowerment, life skills, vocational, women, disaster

\begin{abstract}
Woman empowerment is one important and appropiate action to the area because there is rarely education which focus on build productive skills of woman to using local wisdom to be more useful. This research aims to develop women competence in disaster vulnerable village to understand and manage a local wisdom through vocational life skills education in context of increasing quality of the family and community socioeconomy. The research is action research which has steps include issue analyzing, planning, implementation, and evaluation of action. The action is vocational life skills education. Its research subjects are 25 women in Sengir Village, Kalirejo, Kokap, Yogyakarta as target group. They chosen by the local government consideration and the group characteristic such as wifes of people producing coconut essence, who are till productive and motive to develop. Data collected by interview, observation, and questionnair and analyzed by qualitative analysis techniques. The data validity obtained by perseverance of observation, triangulation, and expert validation. The results of study reveal that the target group was able to develop awareness of utilization of the local potential, having attitudes, knowledge and skills of its production, and creating of the joint business. The existence of women's empowerment makes it more productive in economic activities in order to achieve their welfare.
\end{abstract}

(C) 2019 PLS PPs UNNES

\footnotetext{
Address correspondence:

Departmen of Nonformal Education, Graduate Program, Universitas NegeriYogyakarta

Street Colombo No.1, Karang Malang, Caturtunggal, Kec. Depok, Kabupaten Sleman,

Daerah Istimewa Yogyakarta, Indonesia

E-mail: tohani@unv.ac.id
} 


\section{INTRODUCTION}

Natural disasters are interpreted as an event that occurs suddenly and endangers the damage to people's functions and causes human, material, economic and environmental loss where this exceeds human ability to cope with the resources they have. Natural disasters can take the form of geophysical disasters such as earthquakes, landslides, tsunami and volcanic activities, such as extreme floods and snow, climatological disasters such as extreme weather and fires, meteorological disasters such as storms, tornadoes and cyclones, or biological disasters such as epidemics and insect disorders. Disaster results in material and nonmaterial impacts on life such as damage to machinery and infrastructure, destruction of production of goods and/services, damage to environmental management and non-material losses in the form of deaths, mental health problems, and disruption of social stability in society. So, community need to be developed to have resilience to disaster (Davis \& Davies, 2018; Kwok, et al. 2018; Every \& Richardson, 2018).

The presence of natural disaster is a challenge for women as a group that ranges from the impact of disasters in order to improve the welfare of the family's economic life. Women are required to be productive in generating economic benefits. However, it is unfortunate that majority of women who are classified as productive are predominantly working as housewives who lack of expertise in producing economic value products/ services. This can be seen from the research findings that women in disaster-prone villages in their daily activities tend to be indirectly involved in economic activities, more their activities related to the domestic interests of the household, helping to produce husband's work, and act as laborers on the plantation are many women who function as tree seed growers with daily pay/ payroll systems (Tohani \& Wibawa, 2017).

One of the productivity factor of low disaster vulnarable village women is the lack of ability to utilize natural potential which can be used as a means to increase family economic income. The natural potential possessed by a society includes natural geography, biological diversity such as raw materials for bamboo, banana, mlinjo, medicinal plants, and tubers, and animal diversity in the form of fisheries and livestock. In addition, the socio- cultural potential can also be developed as capital to develop the quality of life. All of these potentials must be utilized by community members independently and participatively in order to obtain optimal economic benefit.

Women in disaster vulnarable village need to get empowerment activities especially in increasing their productivity in the economic field by utilizing local potential to have a psychological, economic and socio-cultural resilience to disaster. They need to obtain empowerment efforts which are essentially instrument to provide strength to the target group who are deemed disadvantaged in terms of opportunities for life, institutions, utilization of resources, economic activitiy, and defining needs and ideas (Mclaughlin, 2016). The education process is one of the efforts that can be implemented to empower women. So, they could be ready to learn, adapt and cope with disaster (Kagawa \& Selby, 2012; Fahey \& Berry, 2016).

Empowerment intervention could be created by doing a vocational life skill that is intended to improve the community skills to produce economic product or service. It can be done by government or community institutions in context of the fulfillment economic needs of community members and families. Using the educational activities, hopefully woman can improve their capability to optimal all potential possed by community both natural potential or socioculture to solve community problems.

Vocational Life Skills Education (VLSE) is deemed important program, especially related to vocational skills. This is because of the economic aspects of families and rural communities prone to disasters are important dimensions that need to be anticipated in order to the fulfillment of people's living needs could be maintained and continued when a disaster occurs. Through this education, it is expected that the community members can develop the quality of individuals and aggregate (community) through solving the problems they face. In the perspective of individual quality, the education program is able to make every student have the skills needed by him and his community. Whereas the aggregative perspective means that the output of education is required to have a composition of expertise that is in accordance with the direction of change in the community 
environment (Sumarno, 2002; in Prasetyo et al., 2017). Besides that, in reality this education has not developed much even education in disaster areas tends to be done with a focus on disaster conscious education which is intended to build awareness and readiness to anticipate natural disasters and related to disaster evacuation processes (Tohani \& Wibawa, 2017).

Life skills are adaptive abilities and positive behaviors that allow individuals to act effectively on daily life's demands and changes. Francis (2016) states that life skills are the ability to overcome stress and frustration in a changing life (www.macmillanenglish.com/life-skills). It is capability that person needs to dare for facing life and life problems fairly without feeling anxious, depressed, then proactively and creatively looking for and finding solutions so that he is finally able to overcome them in order to create a prosperous life (Bernhardt, Yorozu \& Medel-Añonuevo, 2012). It needs to be mastered by everyone in facing the challenges of life changes that contain a variety of intense competition in meeting the needs of life (Rich, 2008).

The dimensions of life skills understood to be diverse. Griffin, McGaw \& Care (2012) argue that life skills are grouped into four categories, namely: (a) ways of thinking includes creativity and innovation, critical thinking, problem solving, and decision making, and metacognition, (b) ways of working includes communication and collaboration, (c) tools for working consist of information literacy and technology literacy, (d) living in the world includes citizenship, career and life, and social and personal responsibility. Trilling $\&$ (2010) related to the context of modern life, life skills can include three important things namely ability of innovation and learning, skills related to the use of technology, media and information, and skills related to employment / career and life. The same thing stated by Marilyn, Norman \& Jordan (2009) who found the 4-H life skills model, namely: hands that have the dimension of giving and working, head that has dimensions of managing and thinking, heart that has dimensions of relations and concern, and health includes dimensions of the healthy being and life.

Implementation of the educational program must be carried out with appropriate management both philosophically and practically (Mwasalwiba, 2012). For learning practically, according to the Ministry of Education and Culture (2003) traits of the learning of life skills are occurring: (a) process of identifying learning needs, (b) process of awareness to learn together, (c) alignment of learning activities to develop themselves, study, independent business, joint efforts, (d) process of mastering personal, social, vocational, academic, managerial, entrepreneurial skills, (e) process of providing experience in doing work properly, (f) producing quality products, (g) process of mutual learning from experts, (h) competency assessment process, and (i) technical assistance to work and form joint ventures .

On the other hand, the education needs to be developed by optimizing local potential as a form of local wisdom. The local potential of community can be related to natural potential in the form of fertility and the beauty of geography, the potential of flora in the form of flora diversity, animal potential and socio-cultural potential such as arts, traditions, positive values and beliefs, and potential human resources used for community empowerment. The utilization of local potential is possible to ensure the positive involvement of the target groups in the education process. They have freedom and opportunity to participate optimally in learning, which ultimately builds their commitment to apply educational outcomes. Therefore, this education needs to be conducted by managers who have professional competence, ability to think critically and creatively in finding solution of problems, and able to optimize local potential and community involvement for its success through a dialogical empowerment process (Baumgartner \& Sandoval, 2018).

\section{METHODS}

This research is an action research carried out to develop awareness and ability of the target groups for developing themselves and their communities. In this study, the cyclce of action done with stages including: issue review, planning, implementation of actions, and evaluation of actions (McIntyre, 2007). It conducted on June October 2018. The target group is 25 women in Sengir hamlet, Kalirejo, Kulon Progo, Yogyakarta, aged 30 - 55 years, as wife of who producing coconut essence, and motivate to develop. 
Determining of the target group considerate thought of the local government and the characteristics of the Sengir community members considered to be able to work together and want to progress.

Data collected by interviews, observations, and questionnaires. Depth interviews conducted to target groups, empowerment cadres, community leaders and local village governments. Observations are made to determine natural and social conditions of the community and impact or potential of the disaster occurred. While the questionnaire is used to determine the achievement of the results of the provision of vocational education actions. The data analyzed by qualitative and quantitative-descriptive analysis techniques and validated by triangulation and extend time of observations, and for questionnaires validation achived by education experts.

\section{RESULTS AND DISCUSSION}

Based on the purpose of study, the results of study could be described below refer to the stages of action research which consist of: determining issues, planning, implementing, and evaluating actions.

\section{Determining issues}

Discovery of the issue was carried out collaboratively between the researchers and the parties involved through in-depth interviews and observations. Interviews conducted to get information on the problems of faced, natural potentials owned, and problem-solving solutions. The interviews were conducted first with the Kalirejo community leaders, namely dukuh chosen purposively, representatives of the target groups, managers of the self-help organizations in the disaster field, empowerment cadres, and the village head of Kalirejo. To support the information obtained, direct observation was carried out to find out the activities of the residents, the potential and the impact of the disaster that had occurred in Kalirejo.

The findings of issues indicate that firstly there is a lack of women's ability to utilize local potential to increase the level of economic welfare both families and communities where most of them are housewives who help their husbands as tangerines, there are many local potentials such as plants, fauna and nature but it is not yet realized that its meaningfulness and has not been utilized by the community becomes an economic product; and secondly it was agreed that to improve the ability of women to utilize local potential, vocational educational program would be carried out as a solution to community problems so that they function to be more effective and accountable for improving the economic welfare of families and communities. The vocational skills education is more directed at utilizing local potential in the form of making culinary products made from melinjo.

\section{Vocational Skills Education Planning}

In accordance with the findings of the issue, the researchers then compiled a series of the vocational education activities that will be carried out. The preparation of the education, for the first stage it was prepared by the researchers their self, and then communicated to the target group at a joint coordination meeting to obtain inputs of its feasibility. The agreed educational actions are shown in table 1 below. Furthermore, researchers also prepare technical matters that support the implementation of learning together with the target group as learner in order to succeed such as agreeing on the place of activity, technical implementation of the learning, informal communication with technical speakers of the education and training, preparation of the evaluation instruments, preparation of the learning materials and tools, and so on. 
Tabel 1. Plan of Vocational Skill Learning Process

\begin{tabular}{|c|c|c|c|c|}
\hline Time & Step & Aims & Method & Implementer \\
\hline \multicolumn{5}{|c|}{ August, 23th 2018} \\
\hline \multirow[t]{2}{*}{$09.00-13.00$} & Awareness & $\begin{array}{l}\text { Explain the objectives of PKH learning } \\
\text { activities and build the motivation and } \\
\text { awareness of the target group }\end{array}$ & $\begin{array}{l}\text { Lecture and } \\
\text { Discussion }\end{array}$ & $\begin{array}{l}\text { Researcher } \\
\text { Target group }\end{array}$ \\
\hline & $\begin{array}{l}\text { Entrepreneurship } \\
\text { based on local } \\
\text { wisdom }\end{array}$ & $\begin{array}{l}\text { Providing insight to target groups regarding } \\
\text { entrepreneurial activities that can be } \\
\text { developed in the Kalirejo region }\end{array}$ & $\begin{array}{l}\text { Lecture and } \\
\text { Discussion }\end{array}$ & $\begin{array}{l}\text { Researcher } \\
\text { Target group }\end{array}$ \\
\hline \multicolumn{5}{|c|}{ September 1st 2018} \\
\hline $08-14.00$ & Learning practice & $\begin{array}{l}\text { Providing knowledge and skills of the local } \\
\text { potential processing production }\end{array}$ & $\begin{array}{l}\text { Lecture } \\
\text { Learning by } \\
\text { doing }\end{array}$ & $\begin{array}{l}\text { Expert } \\
\text { Researcher } \\
\text { Target group }\end{array}$ \\
\hline \multicolumn{5}{|c|}{ September 2 nd - October $2^{\text {nd }}$} \\
\hline $\begin{array}{l}\text { According to } \\
\text { group }\end{array}$ & $\begin{array}{l}\text { Independent } \\
\text { Practice }\end{array}$ & $\begin{array}{l}\text { Providing independent learning experiences } \\
\text { to target groups in producing local potential }\end{array}$ & $\begin{array}{l}\text { Learning by } \\
\text { doing }\end{array}$ & $\begin{array}{l}\text { Researcher } \\
\text { Target Group }\end{array}$ \\
\hline \multicolumn{5}{|c|}{ October 14 th 2018} \\
\hline \multirow[t]{2}{*}{$\begin{array}{l}12.00- \\
17.00 \mathrm{WIB}\end{array}$} & $\begin{array}{l}\text { Group } \\
\text { Strengthening }\end{array}$ & $\begin{array}{l}\text { Developing awareness of the target group } \\
\text { entrepreneurship, togetherness, mutual } \\
\text { belonging and commitment to advance } \\
\text { group business }\end{array}$ & $\begin{array}{l}\text { Brainstorming } \\
\text { Discussion }\end{array}$ & $\begin{array}{l}\text { Researcher } \\
\text { Target Group }\end{array}$ \\
\hline & Joint Reflection & $\begin{array}{l}\text { Obtain an overview of the mastery of } \\
\text { attitudes, knowledge, and skills of the target } \\
\text { group }\end{array}$ & Discussion & $\begin{array}{l}\text { Researcher } \\
\text { Target Group }\end{array}$ \\
\hline
\end{tabular}

After preparing, the researchers coordinated with the government and local community leaders. They were informed to objectives and implementation of the activities and also asked to support for the target groups for optimizing the potential of nature. Result of the coordination is the support of the local government that is very positive towards the implementation of the target group development activities.

\section{Implementation of the vocational skills education}

The VSLE held by running the mechanism of adult learning which includes stages of awareness, practical learning, independent practice, and group strengthening, as well as joint reflection. The first stage, which is awareness raising, done by giving taught to the learners at the hamlet in Padukuhan Sengir. Before learning begins, researchers condition them for the purpose of gaining comfort in learning, by asking them to enter the meeting room and sit more circularly to be more interactive and allow them to enjoy the available food. Furthermore, learning process is opened by researchers by asking all those present to pray, and providing information on the purpose of the learning activities.
Furthermore, the educational material delivered by researchers in a comfortable and familiar atmosphere. This learning intended to raise their awareness and provide them an understanding of the importance of local potential utilization in the form of natural wealth, one of which is the potential of melinjo trees which are widely available in the community and could be used as economic goods such as chips which are ready to be sold to the market. Through discussion of the entrepreneurial cases, researchers try to foster their awareness of the urgency of acquiring vocational knowledge and skills that can improve the level of living welfare for themselves and their environment. Also, it was emphasized that the vocational education is expected as means to increase their productive capabilities in producing chips so that they can be independent or help their husband in meeting family needs. Towards the researcher explanation, the target group can understand what is said by the researcher and respond well to questions of the researcher during the learning process. Positive expressions emerged from the mothers by saying that the education is very helpful because they have been needing practical ability to improve the family's economic quality. Likewise, an empowerment cadre who continues to contribute to 
the development of the community views this activity as a solution for the mountain communities that have many problems.

At the end of the learning researcher gives an overview of the learning plan for next time and at the same time asks for an agreement with them of the technical learning which will be carried out. The aggreemets achieved includes the next learning process that is the practice of emping melinjo production which will be held on next week by consideration of the many affairs of the learning community, the place of learning agreed in the environment of Sengir dukuh house, and the ability to provide practice materials that can be provided by the target group such as firewood, stoves, etc. Finally, the learning process was closed along with saying thanksgiving.

The second stage, further learning managed in accordance with the agreed schedule. The learning objective of this stage is to provide attitudes, knowledge and skills to the target group in producing economically valuable products based on the utilization of local potential, namely to provide productive skills regarding processing of melinjo chips as agreed upon from the beginning in coordination with representatives of learning residents. The learning process was facilitated by technical speakers who came from the Pandak subdistrict, Bantul, which was a craftsman and businessman who had been working for a long time. $\mathrm{He}$ assisted by two other craftsmen who were recruited by themselves. Acquisition of the expert done by direct communication or meeting between researchers and him. The learning process take place from 9 a.m to completion by prioritizing the practice of production directly for all the members. Tools used to include the practice materials were brought directly by the speakers on agreement with researchers and the learners such as forging stones, stackers, steel cathel, melinjo, plastic mat, filter, sand to roast, etc.

The learning process of the production of melinjo chips done by steps i.e. opening, core learning, and closing. After the target group members are conditioned, in the main room of the house by circular position, the researcher opens the learning activities by giving greetings and praying first. Furthermore, it is delivered to the members that the learning objectives is to provide direct experiences in making of the emping melinjo and explaining experiences of the expert and his competence in the implementation of the business and his address.

After the opening, the core learning activity delivered by the expert in three sessions which are delivery of theory, direct practice, and evaluation. The theory delivery session was intended to convey knowledge of the importance of melinjo chips, business opportunities of the melinjo chips, selection of the raw materials, production process of the melinjo chips, equipment needed, and types of the melinjo chips and their processed products. Submission of the material by the expert is in an atmosphere that is relaxed, intimate, and uses both local and national language so that it is easy to understand. He also often allowed the members to reveal questions if there are the material or terms were not understood when the lecture took place. It is show that three of them asked how to choose good melinjo seeds, find out the pounding stone, or benefits to selling chips. For these questions, he provides a clear explanation through using understood language. 
After the theoretical learning thought, the practice of local potential production held in the form of making emping melinjo. It done in groups according to the number of practice equipment used as many as 2 sets of stoves. Assisted by each of the expert assistants who gave examples of the production activities, the learners trained to make emping melinjo starting from choosing of melinjo, measuring the maturity level of melinjo, opening the shell of melinjo, pounding melinjo on the rock, and choosing which results or chips were good or not nice. They were in turns to practice knowledge and skills of the making chips. While the learners have been practicing, the others who have not had the opportunity to practice immediately pay attention to how to make chips. The experts provide important explanations communicatively to them for example how to accumulate well-cooked melinjo, showing the error in the results of chips being made, the technique to quickly peel the melinjo, and the correct position of the forging stone.

Their enthusiasm in the production of emping melinjo is very good. It could be seen from their desire to practice the learning substance delivered by the experts even though alternately. The learning atmosphere is quite familiar, communicating with each other, and sometimes interspersed with jesting both among the learners, and with researchers and with experts. When a learner has enough opportunity to practice it, she could rest and interact with others in the main room of the house. An atmosphere like that occurs until all of them can experience the practice of making emping melinjo.

The next session of the learning was evaluation that is managed after the learners come and sit in the room by circle. It done by asking the learners whether they felt behavior change and have knowledge after finishing the direct practice of production. Some learners expressed their views that were almost the same, namely what they experienced was something completely new and quite encouraging. The practical learning provides excellent new skills to improve their ability to meet their economic needs. Before this evaluation finished, it was agreed that the result of learning would be practiced independently.

The third stage is independent practice assignments. Independent practice designed for one month according to mutual agreement. It run by the learners by applying mechanism of learning used small groups methods. Small groups were formed as many as 3 groups based on the proximity of the area where learners lived, namely: middle, north, and south. The learning process held alternately in which each group conducts learning one day a week for one month. Coordination regarding implementation is carried out by the management of groups formed independently by themselves. The results of assignment are a business group was formed called mekar kusuma, the learners were more able to make emping independently and had sold their product even though it was still limited, and there are a division of labor of the producing of melinjo chips.

The fourth stage is the strengthening of target group and mutual reflection. Strengthening is intended to provide encouragement to the learners so that they are more able to try to increase economic income in groups. In this learning process, education content is conveyed, namely entrepreneurial values and how successful businesses must be carried out in groups. By using discussion method and sometimes speaking local languages (Java), researchers provide explanations and experiences both directly and other people's experiences associated with the process of good entrepreneurship for example entrepreneurs must be dare to take risks, diligently in trying, not giving up quickly, always optimistic, etc. In addition, researchers provide understanding of the development of business in groups with method of brainstorming and delivere real experience of the management of group business that is similar and successful.

After that, mutual reflection done by researchers and the learners specifically in interpreting of the learning process they experienced. Based on the opinion of learners, it is known that the process is very useful in order to improve the family's economic capacity and 
hoped that there are follow-up learning in the future.

\section{Vocational education evaluation}

To ensure implementation of the VSLE for women successfully, the learning process and outcome was evaluated. Process evaluation carried out by using observation and interview method during and after the learning process take place. To find out the results of learning, method of giving questions is also done by reasking the educational substances which has been delivered whether it is understood or not. It is known that in the learning process, they was seen as enthusiastic and have strong awareness to advance the group. This fact indicated by an expression stating that they actually have a lot of natural potential, but have not been able to be utilized, feel happy to get vocational training, ask for an explanation of the material to the expert well, and the learning activities provide excitement to them.

Evaluation of the learning outcomes conducted by using questionnaire method. Based on result of the evaluation, it is showed that knowledge and skills of the target group inf term of the production of melinjo chips increased or in the good category (mean score 3). The output viewed good things because of the training provided was still in its initial stages and first time conducted to the target group. It could be presented in the graph below.
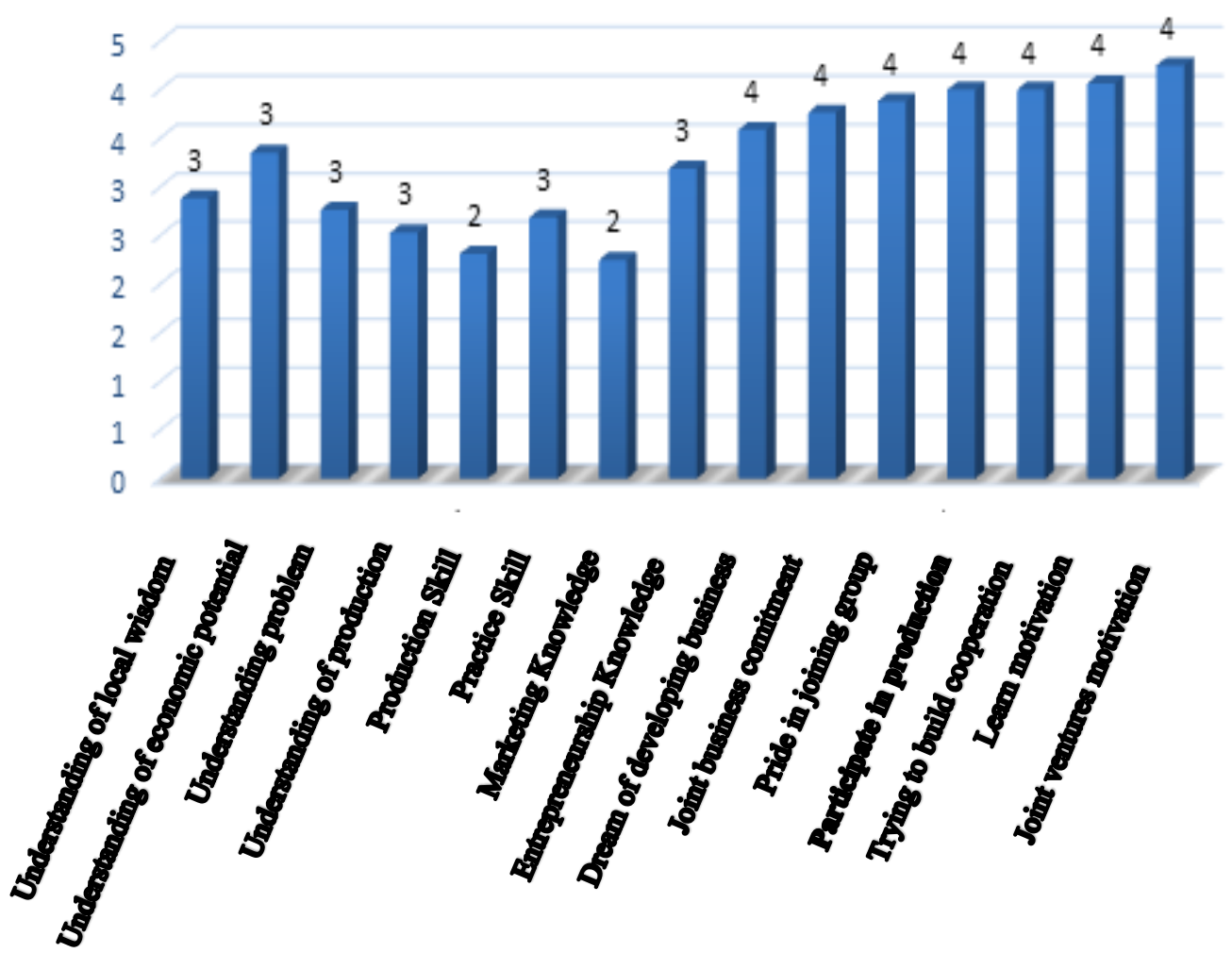

Figure 1. Learning outcomes of the target group

The qualitative statement of the learners also showed that the education process they participated in seen as very useful and they hoped that progress could be achieved through the implementation of learning outcomes in production of the local potential. They felt that VSLE could provide knowledge to increase their economic quality, able to produce chips, being happy and eager to build business activity and also, they expected to gain facilitation of capital, equipment, or groups to be more advanced. Thus, it can be concluded that there has been a change in the positive behaviors of the target group who have been vocated.

The VLSE for Kalirejo women is carried out based on utilizing of local potential which is one of the activities to produce positive changes 
in the life of the Kalirejo community. This education is interpreted as an action to empower the target group by providing various attitudes, knowledge and skills that are directly useful to overcome the problems faced based on the utilization of the potential of community. It seeks to help individuals overcome the problems they face so that they can be independent in meeting the needs of both individuals and groups. Through this activity, productive vocational skills of the community members can be formed namely they have awareness, knowledge, and vocational skills used to improve their quality of life especially in income generating.

The results of study show that there is a change of the learner's behavior including awareness of the problems and the local potential of community, having desire to improve the quality of life, having knowledge and skills in the processing of local potential based products, and being able to develop productive economic activities together. Achieving these learning outcomes are not separated from the motivation of women as learners to advance their economic lives, which so far have not been economically productive. Motivation energizes someone to develop (Nurhayati, Sutarto, Mulyono, 2018; Senjawati \& Fakhrudin, 2018) or vice versa to be a barrier to empowerment (Lestari \& Suminar, 2016). Besides motivation, knowledge of the local potential makes they is easier to be empowered (Indrianti et al., 2017). So, realization of the awareness and motivation regarding of needs and problems of the target group guarantees vocational education activities could be achieve the expected goals (Desjardins, 2010).

Seeing the positive behavioral changes of women meant that the goal of VLSE which were carried out could be achieved even though it still needed to optimize the implementation of learning outcomes. This is in line with several findings which state that education for women becomes a tool to make women smart and independent (Sutisna, 2013; Jatingsih \& Andayani, 2014; Tohani, 2011; Saripah \& Shantini, 2016). However, Caffarella \& Daffron
(2013) state that educational success is influenced by the opportunity to practice learning outcomes and environmental conditions. Ideally, the change in behavior of the target group is not limited to the learning outcomes obtained but further it is how the learning outcomes could be manifested in the management of economic activities. So, to obtain rapid changes, the educational activities to develop target groups need to be done by organizing of the learning opportunities which support output applying quickly for example by providing business incubators, marketing training, and using technology which is relevant to success of the target group's business.

VLSE as an educational effort of the people development must be conducted continuously and remains initiated through the wishes and abilities of the target group. In this case, in order to be competent and able to achieve its objectives, the target groups must firstly make changes on their perspective, attitudes, knowledge and skills associated with the implementation of the local resource management by creating and developing of the shared learning behavior or managing knowledge through social learning in which their attitude and behavior to learn can develop (Cincera, 2013). That is, to produce a renewal in improving the economy of the family or society, they must be brave and able to produce innovative breakthroughs in producing of economic products through the reinterpretation of meaningful experiences which they already have in order to become experiences that lead to innovation (Kolb, 2014) and build strong soul and entrepreneurial capacity to be able to compete and get opportunities or resources in the community.

\section{CONCLUSION}

Based on the results of study, it concluded that the VLSE based on utilization of the local potential for women of the disaster vurnerable village give positive learning outcomes to its target group which includes: learner was able to increase awareness of using the local potential of community, have awareness of the urgency of local potential, have 
an attitude, knowledge and skills in utilization of the local potential, able to produce the valuable products made of the local raw materials, and able to work together in groups. However, learning outcomes in term of the increased income have not been optimal because it as empowerment activity is still on early stages. Therefore, another development action are needed which enable the target groups apply the attitudes, skills, and knowledge possessed in the entrepreneurial implementative activities.

Some suggestions stated i.e. the target group have to be more committed to carrying out the production of melinjo chips for increasing economic income, inform its existence to the surrounding of community so that community can receive and support its existence, and more intensively coordinate with relevant parties by open communication to establish good perceptions and optimize the use of facilities provided by the local government; the local village government needs to provide greater facilitation in the form of material and nonmaterial support for accelerating of the development of mutual business possed by the group; and researchers need to provide continuous project assignment learning to ensure all individuals can master optimal skills. 


\section{REFERENCES}

Baumgartner, L. M., \& Sandoval, C. L. (2018). "Being a Presence to Each Other": Adult Educators Who Foster Empowerment with Incarcerated Women. Adult Education Quarterly, 68(4), 263-279.

Bernhardt, A. C., Yorozu, R., \& MedelAñonuevo, C. (2014). Literacy and life skills education for vulnerable youth: What policy makers can do. International Review of Education, 60(2), 279-288.

Caffarella, R. S., \& Daffron, S. R. (2013). Planning programs for adult learners: A practical guide. John Wiley \& Sons.

Care, E., Griffin, P., \& McGaw, B. (2012). Assessment and teaching of 21st century skills. Springer.Cincera, J. (2013). Experiential Learning in Education for Sustainable Development: Experiences from a Czech-Kazakh Social Learning Programme. Journal of Education for Sustainable Development, 7(1), 23-37.

Davies, T. R., \& Davies, A. J. (2018). Increasing communities' resilience to disasters: An impact-based approach. International journal of disaster risk reduction, 31, 742-749.

Desjardins, J. (2010). Participation in adult learning. Dalam Rubenson, Kjell. (2011). Adult learning and education. Oxford: Academic Press.

Every, D., \& Richardson, J. (2018). A framework for disaster resilience education with homeless communities. Disaster Prevention and Management: An International Journal, 27(2), 146-158.

Fadel, C., \& Trilling, B. (2010). 21st Century Skills: Learning for Life in Our Times. Education Review//Reseñas Educativas.

Fahey, S., Verstraten, L., \& Berry, A. J. (2016). Education for sustainable development: Enhancing climate change adaptation expertise in developing countries. Journal of Education for Sustainable Development, 10(1), 54-67.Francis, M. (2016). Life skills education. Retrieved from www.changingminds.org

Indrianti, D. T., Khutobah, K., \& Latif, M. A. (2017). Potensi Kearifan Lokal dalam Pendidikan Keaksaraan Fungsional pada Masyarakat Perdesaan di Kabupaten
Jember. Journal of Nonformal Education, 3(2), 140-148.

Jatiningsih, O., Listyaningsih, L., \& Andayani, A. (2014). Penguatan Fungsi Edukasi Pkk: Pendidikan Gender untuk Membangun Kehidupan Demokratis. Cakrawala Pendidikan, (1).

Kagawa, F., \& Selby, D. (2012). Ready for the Storm: Education for Disaster Risk Reduction and Climate Change Adaptation and Mitigation1. Journal of Education for Sustainable Development, 6(2), 207-217.

Kolb, D. A. (2014). Experiential learning: Experience as the source of learning and development. FT press.

Korten, D. C. (1986). Community management: Asian experience and perspectives. Kumarian Press.

Kwok, A. H., Paton, D., Becker, J., HudsonDoyle, E. E., \& Johnston, D. (2018). A bottom-up approach to developing a neighbourhood-based resilience measurement framework. Disaster Prevention and Management: An International Journal, 27(2), 255-270.

Lestari, D. P. (2015). Pola Pembelajaran Program Kecakapan Hidup (Life Skill) Menjahit di BLK Kabupaten Pekalongan (Doctoral dissertation, Universitas Negeri Semarang).

McIntyre, A. (2007). Participatory action research (Vol. 52). Sage Publications.

McLaughlin, K. (2016). Empowerment: A critique. Routledge.

Merriam, S. B., \& Brockett, R. G. (2011). The profession and practice of adult education: An introduction. John Wiley \& Sons.

Marilyn N., Norman \& Jordan, Joy C. (2009). Targeting life skills in 4-H. Retrieved from http://edis.ifas.ufl.edu/4h242

Mwasalwiba, E. S. (2012). Entrepreneurship education: a review of its objectives, teaching methods, and impact indicators. IEEE Engineering Management Review, 40(2), 72-94.

Nurhayati, E., Sutarto, J., \& Mulyono, S. E. (2018). Motivation as Mediation Variable in the Effect of Knowledge Level and Socio-economic Status to Participation of PUS (Couples of Reproductive 
Age). Journal of Nonformal Education, 4(1), 25-36.

Prasetyo, I., Tohani, E., \& Rohadi, A. S. Pemetaan kebutuhan pendidikan kecakapan hidup di kawasan wisata karst Pracimantoro, Wonogiri, Jawa Tengah. Jurnal Penelitian Ilmu Pendidikan, 10(1), 22-29.

Rich, D. (2008). MegaSkills $@$ : Building Our Children's Character and Achievement for School and Life. Sourcebooks, Inc.

Saripah, I., \& Shantini, Y. Implementasi model pembelajaran mandiri program pendidikan kecakapan hidup perempuan. JPPM (Jurnal Pendidikan dan Pemberdayaan Masyarakat), 3(2), 176-186.

Senjawati, Riski Arum. \& Fakhruddin, Fakhruddin. (2017). Motivasi Warga Belajar dalam Mengikuti Pendidikan Kesetaraan Program Kelompok Belajar
Paket C di Pusat Kegiatan Belajar Masyarakat Tunas Bangsa Brebes. Journal of Nonformal Education, 3(1), 40-46.

Sutisna, A. (2013). Model Pemberdayaan Perempuan dan Pengarusutamaan Gender melalui Layanan Pendidikan Masyarakat pada Pusat Kegiatan Belajar Masyarakat. Jurnal Cakrawala Pendidikan, 3(3).

Tohani, E. (2011). Pendidikan nonformal dan pengurangan kemiskinan di pedesaan. Walisongo: Jurnal Penelitian Sosial Keagamaan, 19(2), 385-398.

Tohani, E., \& Wibawa, L. Peran modal sosial dalam penanganan bencana pada masyarakat desa rawan bencana Gunung Merapi. JPPM (Jurnal Pendidikan dan Pemberdayaan Masyarakat), 5(2). 